\title{
Self-management support of adolescents with type 1 Diabetes Mellitus in the light of healthcare management
}

\author{
Autocuidado apoiado de adolescentes com Diabetes Mellitus tipo 1 à luz da gestão do cuidado \\ Autocuidado apoyado de adolescentes con Diabetes Mellitus tipo 1 a la luz de la gestión de la atención
}

\section{Annanda Fernandes Moura Bezerra Batista' ORCID: 0000-0002-6974-9816 \\ Vanessa Medeiros Nóbrega" ORCID: 0000-0002-2596-8259}

Leiliane Teixeira Bento Fernandes" ORCID: 0000-0003-2643-5638

Elenice Maria Cecchetti Vaz" ORCID: 0000-0002-3246-3187

Gabriela Lisieux Lima Gomes"'I ORCID: 0000-0002-7032-2035

Neusa Collet" ORCID: 0000-0002-4795-0279

'University of Illinois at Chicago, College of Nursing. Chicago, United States of America.

"Universidade Federal da Paraíba. João Pessoa, Paraíba, Brazil. "'Centro Universitário de João Pessoa. João Pessoa, Paraíba, Brazil.

How to cite this article: Batista AFMB, Nóbrega VM, Fernandes LTB, Vaz EMC, Gomes GLL, Collet N. Self-management support of adolescents with type 1 Diabetes Mellitus in the light of healthcare management. Rev Bras Enferm. 2021;74(3):e20201252. https://doi.org/10.1590/0034-7167-2020-1252

Corresponding author: Annanda Fernandes Moura Bezerra Batista E-mail: abatis5@uic.edu

EDITOR IN CHIEF: Antonio José de Almeida Filho ASSOCIATE EDITOR: Carina Dessotte

Submission: $12-02-2020$
Approval: 02-15-2021

\section{ABSTRACT}

Objectives: to analyze the self-management support needs of adolescents with type 1 diabetes mellitus. Methods: this qualitative research was carried out between September and December 2017 with nine adolescents in the pediatric outpatient clinic of a university hospital and in their homes. The material collected through semi-structured interviews was interpreted by thematic inductive analysis in the light of the healthcare management concept. Results: adolescents' self-management support needs include longitudinal monitoring by health teams; family support in their training; support from the social network; and a careful look by government officials in the construction of guidelines for dispensing the essential inputs for treatment. However, these needs are not always met satisfactorily, resulting in gaps in this support. Final Considerations: these gaps interfere in resolving health demands. Self-care with fragmented support affects the healthcare management dimensions, making it impossible to meet the uniqueness of adolescents in a comprehensive, expanded and ethical way.

Descriptors: Diabetes Mellitus; Adolescent; Self-Management; Health Management; Social Support.

\section{RESUMO}

Objetivos: analisar as necessidades de autocuidado apoiado de adolescentes com Diabetes Mellitus tipo 1. Métodos: pesquisa qualitativa, realizada entre setembro e dezembro de $2017 \mathrm{com}$ nove adolescentes no ambulatório pediátrico de um hospital universitário e em seus domicílios. O material coletado mediante entrevistas semiestruturadas foi interpretado pela análise temática indutiva à luz do conceito de gestão do cuidado. Resultados: as necessidades de autocuidado apoiado desses adolescentes incluem: acompanhamento longitudinal das equipes de saúde; suporte da família em sua capacitação; apoio da rede social; olhar cuidadoso dos governantes na construção das diretrizes para dispensação dos insumos indispensáveis ao tratamento. Todavia, nem sempre essas necessidades são atendidas satisfatoriamente, resultando em lacunas nesse apoio. Considerações Finais: essas lacunas interferem na resolutividade das demandas em saúde. O autocuidado com apoio fragmentado afeta as dimensões da gestão do cuidado, inviabilizando atender a singularidade dos adolescentes de forma integral, ampliada e ética.

Descritores: Diabetes Mellitus; Adolescente; Autocuidado; Gestão em Saúde; Apoio Social.

\section{RESUMEN}

Objetivos: analizar las necesidades de autocuidado apoyado de adolescentes con Diabetes Mellitus tipo 1. Métodos: investigación cualitativa, realizada entre septiembre y diciembre de 2017 con nueve adolescentes en el ambulatorio pediátrico de un hospital universitario y en sus domicilios. El material recolectado a través de entrevistas semiestructuradas fue interpretado por análisis inductivo temático a la luz del concepto de gestión del cuidado. Resultados: las necesidades de autocuidado con apoyo de estos adolescentes incluyen: seguimiento longitudinal de los equipos de salud; apoyo familiar en su formación; apoyo de la red social; observación cuidadosa de los funcionarios gubernamentales en la construcción de pautas para dispensar los insumos esenciales para el tratamiento. Sin embargo, estas necesidades no siempre se satisfacen de manera satisfactoria, lo que genera lagunas en este apoyo. Consideraciones Finales: estas brechas interfieren en la resolución de las demandas de salud. El autocuidado con apoyo fragmentado incide en las dimensiones de la gestión del cuidado, imposibilitando atender la singularidad de los adolescentes de manera integral, expandida y ética. Descriptores: Diabetes Mellitus; Adolescente; Autocuidado; Gestión en Salud; Apoyo Social. 


\section{INTRODUCTION}

Adolescence is a complex phase of human development with several challenging situations, especially when added to a chronic disease, such as type 1 Diabetes Mellitus (1DM) ${ }^{(1)}$. Mismatches in glycemic management, with hyperglycemic spikes, can sometimes be related to decreased adherence to treatment and adolescents' neglect of self-care, compromising their health ${ }^{(2)}$.

In addition to psychobiology, the transition to adolescence includes modifying the disease management, since adolescents' autonomy in maintaining his therapeutic regime is expected ${ }^{(1)}$. This regime is multifaceted and involves the adolescent's agreement to adopt specific diabetes-related behaviors, such as insulin replacement therapy and blood glucose monitoring throughout life, food management and physical exercise. Thus, 1DM management requires changes in their lifestyle, which often affect psychosocial well-being and satisfaction with body image and self-esteem, which can have a negative impact on the course and prognosis of the disease ${ }^{(3)}$. In a social environment linked to a decrease in parental involvement in activities for the care of pubertal children, self-efficacy perception is associated with an increase in self-care behavior. Self-efficacy refers to the belief of individuals that they have the technical, psychological and knowledge capacity to conduct the essential actions for the implementation of their therapies. In the case of diabetes, it is closely related to glycemic management ${ }^{(4)}$.

Nevertheless, healthcare professionals, through the methodology of self-management support, work together with the family, to strengthen the social support network for adolescents in order to investigate barriers and difficulties that can empower them in 1DM management, in order to prevent injuries ${ }^{(5)}$. Therefore, a close relationship between users and the health team is recommended, in order to define problems, goals, establish and monitor care plans ${ }^{(6)}$. From this perspective, it is essential to have articulation and dialogue between members of multidisciplinary teams in a cooperative relationship, in the sharing of responsibilities ${ }^{(7)}$ regarding care plans. The potential of healthcare management is recognized when using health technologies to meet individual needs, in order to improve adolescents' quality of life, safety, and autonomy, when assisted in the Unified Health System (SUS Sistema Único de Saúde) $)^{(8)}$.

Although self-management support can be enhanced when integrated with the multiple dimensions of healthcare management, for resolving the demands of this population, there are few Brazilian and international studies carried out in this broader perspective of care. When this empowerment occurs, aspects from the individual to the societal dimension that can influence the self-care of adolescents with 1DM are valued, including the singularities inherent to the transition phase, in which they will take responsibility for their treatment. Therefore, the question is: what are the self-management support needs of adolescents with $1 \mathrm{DM}$, from the perspective of healthcare management?

\section{OBJECTIVES}

To analyze the self-management support needs of adolescents with type 1 Diabetes Mellitus.

\section{METHODS}

\section{Ethical aspects}

Ethical precepts in research in force in the country were followed, with the project approved by a Research Ethics Committee. Before starting data collection, the Informed Consent Form (ICF) was presented in its entirety, which was then signed by 18-year-olds or their guardians; when it came to minors, guardians also signed the Term of Assent if they agreed to participate. To guarantee anonymity, participants were identified in the excerpts of the interviews by the letter " $A$ ", followed by an Arabic number corresponding to the inclusion sequences in the research and their age.

\section{Study type, place, and period}

This is exploratory-descriptive research with a qualitative approach, following the recommendations of the Consolidated Criteria for Reporting Qualitative Research (COREQ). Data collection was performed in the pediatric outpatient service of a teaching hospital in Paraíba and at participants' homes, from September to December 2017.

\section{Study participants}

The research participants were adolescents, considering the definition of the World Health Organization as individuals aged between 10 and 19 years old ${ }^{(9)}$, who were adolescents diagnosed with 1DM using insulin therapy. To select them, the convenience criterion was applied through snowball sampling, in which key informants indicated other people who met the research profile $^{(10)}$. Therefore, the selection started in person at the outpatient service. From these adolescents, new contacts were made with others, who contemplated the inclusion criteria.

\section{Data collection}

Data collection was carried out by one of the researchers, a graduate student, trained and with previous experience in qualitative research. Semi-structured interview was used as a technique, mediated by the questions: how has it been the assistance in the health services that you sought from the first signs and symptoms of diabetes to the present day? How has your relationship been with your family, friends and neighbors? How is the care provided by the healthcare professionals who take care of you? How do you get supplies for diabetes treatment?

A previous one-to-one contact was established with ten participants, exposing the research objective to obtain their consent. Only one guest refused to participate in the survey for personal reasons, totaling nine adolescents.

From the initial contact, some interviews took place at the outpatient clinic after consultation with a specialist, ensuring privacy. Only two adolescents chose to conduct the interview at home by prior appointment with their guardians. The interviews were conducted in a reserved place, with the presence of the interviewer and the adolescent alone, and recorded in audio by electronic media, with an average duration of 60 minutes. As a 
closure criterion, saturation was used, when the phenomenon can be identified intensely according to its multiple dimensions through quality of interactions ${ }^{(11)}$.

\section{Data analysis}

The empirical material was subjected to thematic inductive analysis in the light of the concepts of healthcare management and self-management support, whose articulation between both offers new and rich possibilities for analysis. Healthcare management encompasses different dimensions: individual, focused on self-care; family, involves family members, friends and neighbors who contribute to the management of care; professional, addresses professional competence, ethical posture and the ability to build bonds with users; organizational, in which the skill of each professional favors interaction between the team and to achieve common goals; systemic, it is the formalization of regulated connections between health services; societal, which refers to public policies under the responsibility of the State in the formulation and implementation of strategies so that this objective is achieved $^{(8)}$.

Self-management support consists of the following steps: assess (identifying knowledge, behaviors, social life, and health history); advise (sharing constructive information and health education); agree (group formation of a self-care plan based on the information previously obtained in the assessment and in a collaborative way); assist (identification of barriers, motivations, and involvement); arrange (definition of the most effective monitoring according to the patients' profile) ${ }^{(6)}$.

Inductive thematic analysis made it possible to identify, analyze and report standard themes present in the data, as shown in Figure 1. For that, analysis procedures were developed in six stages, which do not follow a rigid sequence: familiarity with the data through the researcher's impregnation on the empirical material; generation of initial codes from similar sets; search for themes, in which the codes were grouped by common themes; theme review, in order to readjust possible new groupings. Finally, there is a definition and final nomination of topics and preparation of a report ${ }^{(12)}$. In the final report of this study, the six healthcare management dimensions were considered in the discussion of the empirical material.

\begin{tabular}{|c|c|}
\hline $\begin{array}{l}\text { Health team } \\
\text { longitudinal } \\
\text { monitoring }\end{array}$ & $\begin{array}{l}\text { - Quality of the bond with the health service } \\
\text { - Professional-adolescent relationship } \\
\text { - Welcoming adolescents' demands }\end{array}$ \\
\hline $\begin{array}{l}\text { Family empowering } \\
\text { adolescents with type } \\
1 \text { Diabetes Mellitus for } \\
\text { self-care }\end{array}$ & $\begin{array}{l}\text { - parental support in the initial phase of care } \\
\text { transition } \\
\text { - exchange of experiences with family members } \\
\text { with diabetes }\end{array}$ \\
\hline $\begin{array}{l}\text { Inputs for self-care } \\
\text { and type } 1 \text { Diabetes } \\
\text { Mellitus (lack of) } \\
\text { management }\end{array}$ & $\begin{array}{l}\text { - irregularity in the availability by the government } \\
\text { - mismatch between need and supply } \\
\text { - bureaucracy in access } \\
\text { - judicialization in guaranteeing the right to health }\end{array}$ \\
\hline $\begin{array}{l}\text { Contribution of } \\
\text { the social network } \\
\text { to acceptance and } \\
\text { quality of life }\end{array}$ & $\begin{array}{l}\text { - school in health education } \\
\text { - supply of inputs for self-care }\end{array}$ \\
\hline
\end{tabular}

Figure 1 - Themes and codes identified in inductive thematic analysis

\section{RESULTS}

Nine adolescents aged between 10 and 18 years participated in the study, most of them male and with a minimum diagnosis time of one year (Chart 1).

Four participants lived in the capital, three, in neighboring municipalities to the east, and two, in the countryside of the state. As for the frequency of visits to the Family Health Unit, it varied between once a week, twice a month, every two months and only to get the blood glucose tape kit. However, four reported not attending this service, as they had a private health plan. Regarding the education of caregivers, three had completed higher education, three had completed high school, one had completed elementary school, and two had not completed elementary school.

Chart 1 - Characterization of adolescents with type 1 Diabetes Mellitus regarding age, sex, education, time since diagnosis, type of treatment, and complications, João Pessoa, Paraíba, Brazil, 2017

\begin{tabular}{|c|c|c|c|c|c|c|}
\hline Participant & $\begin{array}{c}\text { Age } \\
\text { (years) }\end{array}$ & Sex & $\begin{array}{l}\text { Education } \\
\text { (grade/year) }\end{array}$ & $\begin{array}{c}\text { Diagnosis time } \\
\text { (years) }\end{array}$ & Type of treatment & Complications \\
\hline $\mathrm{A} 1$ & 17 & M & $1^{\text {st }} \mathrm{HS}^{*}$ & 7 & Insulin/syringe & Kidney failure \\
\hline $\mathrm{A} 2$ & 10 & $\mathrm{~F}$ & $5^{\text {th }} \mathrm{ES}^{*}$ & 3 & Pen-insulin & - \\
\hline $\mathrm{A} 3$ & 11 & M & $5^{\text {th }} \mathrm{ES}^{*}$ & 4 & Pen-insulin & - \\
\hline A4 & 14 & M & $8^{\text {th }} \mathrm{ES}^{*}$ & 1 & Insulin/syringe & - \\
\hline A5 & 14 & $\mathrm{~F}$ & $1^{\text {st }} \mathrm{HS}^{*}$ & 7 & Pen-insulin & - \\
\hline A6 & 18 & M & Incomplete $\mathrm{HE}^{*}$ & 12 & Pump-insulin/ Pen-insulin & - \\
\hline A7 & 17 & M & $2^{\text {nd }} \mathrm{HS}^{*}$ & 7 & Pump-insulin & - \\
\hline A8 & 17 & M & $3^{\text {rd }} \mathrm{HS}^{*}$ & 13 & Pump-insulin & - \\
\hline A9 & 17 & $\mathrm{~F}$ & $3^{\text {rd }} \mathrm{HS}^{*}$ & 15 & Pump-insulin & Vasculopathy \\
\hline
\end{tabular}




\section{Health team longitudinal monitoring}

Therapeutic itineraries traveled between the public and private sectors of the Health Care Network (RAS - Rede de Atenção à Saúde) are influenced by different factors that can both positively and negatively influence the longitudinal monitoring of these adolescents. As for negative factors, there is a fragile link with the healthcare service and gaps in professional-adolescent-family communication, which make it difficult to support the self-care needs of adolescents with 1DM.

When I was seven years old, they discovered diabetes. I went to the PAM [Medical Assistance Post], but it is being restored, and I was followed up at a health center for many years. I went to a health center and asked the physician for referral to UH [University Hospital], in order to treat diabetes, who referred me here and saw that the service is very good. (A1, 17y)

I showed this last exam to a farm's physician and he said, "you don't have diabetes, boy", then I started to eat everything. But I started to feel dizzy again [...] it was high [blood glucose] again. This time, we went to a private clinic and to the secretariat to book and come here [hospital outpatient clinic]. During that time, I didn't take any insulin. (A4, 14y)

I didn't go, because there [FHS] nobody does anything. I just go there to have my milk teeth pulled out, get a vaccine, when the exam came out. (A2, 10y)

They [Family Health Team/FHS] will give you an injection when I'm sick. But, about diabetes, nobody has ever been there [home]. I would like them [FHS] to help me out, but they do not help [...] encouraging me to eat right and without exaggeration, giving me a diet to follow [...] eating at the right time. I think the nurse could help me more. (A3, 11y)

In contrast, the adolescents made explicit a greater positive impact on the development of self-care in outpatient specialty services, when compared to Primary Health Care (PHC).

[...] the issue of monitoring with her [physician/hospital outpatient] is great. The welcoming of nurses here is very positive, they look at everything, they have a more informal conversation, how is their life, the school, they are in a situation of stress [...] thus more comprehensive in relation to mental health than diabetes in relation to the medication. There has always been a lot of attention to see, to talk, food education, not to increase the dose. $(\mathrm{A} 6,18 \mathrm{y})$

They stressed the relevance of healthcare professionals in the maturation of self-efficacy and construction of autonomy during the transition from childhood to adolescence.

I like it a lot. [...] / created a bond because she [outpatient nurse] put me in the group [adolescents] with diabetes; I attended to the meetings and it was very good. He taught me how to count insulin units, he gave me a doll to apply and demonstrated the spots to apply, [...]. It made me think about what I was doing. Sometimes it goes in one ear and out the other, but other times it got in my head and I did what it said. $(\mathrm{A} 5,14 \mathrm{y})$
An appointment with her [physician] lasts an hour, an hour and a half. We started counting carbohydrates, taking insulin for what I ate and no longer for the protocol. I had a leaflet with the amount of carbohydrates in the food. I passed to the pen [for insulin therapy] and she taught me insulin by correction. (A8, 17y)

Although most reports are positive with regard to the relationship between health professionals and adolescents/family in secondary care, it is possible to identify that, the attitude of some professionals, has not strengthened bonding. In these cases, the appropriate management of the disease was interfered with, delaying adolescents' autonomy for self-care.

$\mathrm{He}$ [physician/MAC] was very radical, there was no time for you to understand things, he just shouted, "you are going to have to eat this and that's it, it's over". He always said, "do you want to look bad? Do you want to be sick?" And you had no other option. I did not like going. My mom adapted things for me at home. [...] sometimes she assisted more than one person at the same time. (A9, 17y)

\section{Family empowering adolescents with type 1 Diabetes Mellitus for self-care}

Transition from childhood to adolescence is a critical phase and coincides with the transition from parental care to children, including those related to health. During this period, family members begin to prepare adolescents with 1DM to manage and monitor their own care and management of the disease. This was considered a stressful phase, as adolescents begin to take on these responsibilities.

In the transition of this care [blood glucose test that the mother did in the early hours], I gradually removed these intensifications. We agreed to do it before bed and if it was low [blood glucose]; I ate before, and also did it as soon as I woke up. [...] as I grew old and matured, it got better because I had more responsibility to myself than my mother. [...] They [parents] help me a lot, [...] they are always there when I need. $(\mathrm{A} 8,17 \mathrm{y})$

When I was 10, I no longer wanted to take care of myself. This transition of care was complicated. My mother started to notice [...]. She and my father took my glucometer and pump every day at night to see if I was taking the test at the right time and if I was telling the pump what I was eating. So, either I did things or they punished me. (A9, 17y)

In addition to parental support, adolescents cited the help of other family members. Support from uncles, grandparents or cousins was perceived as positive, as it allowed the exchange of experiences, initial help in care and contribution to management.

When I discovered [the disease], I went to spend some days at my godmother's house, because there l ate lettuce, tomatoes and vegetables. My godmother took care of my food/lunch. My cousin applied [insulin]. (A2, 10y)

My grandfather also has diabetes, but his was type 2. He always said, "look, I'm going to eat this here with you, we can eat this here for lunch". So, he always made me see that none of that made me different. (A9, 17y) 


\section{Inputs for self-care and type 1 Diabetes Mellitus (lack of) management}

The State has not guaranteed a continuous input supply for the adequate management of diabetes. Essential inputs for daily and uninterrupted use are lacking and, when available in the public health network, access to them is limited and bureaucratic, constituting an important barrier, especially to low-income families who cannot afford to provide them.

The blood glucose device supplies picked up in the FHS Health District and the insulins picked up at NAF [Pharmaceutical Assistance Center] in the neighborhood. It is complicated because it has been three months without Lantus [insulin]. This is very stressful because they have all this carelessness and, when they have insulin, it is the biggest bureaucracy to get it. (A6, 18y)

There is a mismatch between the needs for inputs for proper 1DM management and the effective availability of these by managers.

The government wants to say how many strips [glucose strips] I will use. If the physician says I have to do the test eight times a day, but the government only gives three strips a day. In addition, not always when we do it works, sometimes errors happen. (A7, 17y)

[...] I need to take the blood glucose device to see how many times I do the test, and the insulin pen, to see that I'm using the amount they give me. They check the lot to see if you are delivering the ones they gave. If you do not deliver all of them, you will receive less. And they always ask for a recipe [...] arranging things so as not to provide [...]. Every three months I have to have a new prescription signed by the physician, justifying the amount because I use carbohydrate count. If there is a change in the protocol, they will ask for medical tests to prove the need. So, it is [an attitude] disrespectful and unnecessary, from my point of view. (A6, 18y)

In the daily lives of these adolescents with 1DM and their families, the lack of supplies was reported as a common experience, regardless of the device used: pen, syringe, or, mainly, insulin pump, mitigated by a network formed by other families in the country.

I received supplies [from the insulin pump] for six months. I started using [...] but I took it out because I had no more inputs. [...] I have the insulin pump standing at home without inputs to change. (A6, 18y)

My father bought insulin and strips [blood glucose strips] for seven months. Only my mother started to join [virtual] groups from all over Brazil and there was always someone to exchange or donate. Now I am living on donations from these people [...]. (A7, 17y)

Adolescents and their families faced the consequences of neglect, experiencing constraints and having to resort to judicialization of health to have guaranteed rights.

In addition to what diabetes already causes in me and even more this disorder, am I really having quality of life? Because I could be taking care of other things in my life, such as work and studies, but I need to spend hours in line and embarrassment in order to be able to have the medicine and still not take it because I don't have it or because of bureaucratic issues. I don't know how to specify [the fault] [...] I believe it is a set of everything that, when I'm going to collect my rights, I can't do it. (A6, 18y)

It appears that five users of [insulin] pumps have started to receive inputs through lawsuits. We are hopeful that mine will come in the new wave. My mother is always in contact with the government and [name of the medical technology company] to see if the conversations between the government and the company match, but they never match. (A7, 17y)

Thus, there are weaknesses in the connections between services for resolving the health problem of adolescents with 1DM and in public policies that guarantee input supply, especially for users of insulin pump.

My biggest difficulty is the lack of pump inputs or the difficulty to get insulin or strips [...] it is something that the government does not see. $(\mathrm{A6}, 18 \mathrm{y})$

They [rulers] could fulfill what is our right [...], if every six months or three months it is their obligation to give us the inputs, they should do it. We fulfill our obligations, why don't they do the same? This is very annoying. $(\mathrm{A} 8,17 \mathrm{y})$

\section{Contribution of the social network to acceptance and quality of life}

The school was a source of support for adolescents with 1DM by developing actions that facilitated the care of the disease, lectures or classes on the disease and the fight against bullying.

After I had these symptoms [hypoglycemia], the social worker gave priority to those who have problems at school, like me, to be one of the first to be able to have a snack. Very good, because now they [social workers] have seen what diabetes was like and are trying to help me at school. The biology professor, when he went to explain diabetes, he used me as an example and I liked it a lot. My friends saw that it was a very interesting thing and even asked some questions about it and stopped bullying after the lecture at school. (A1, 17y)

Friends, who also have diabetes, were instrumental in supporting the purchase of supplies and acceptance of the disease.

I can count on people I shouldn't count because they [friends] are under no obligation to help me. They give [inputs] even though they know they may be lacking. This has united and created bonds with others with diabetes to try to solve some problems common to all. $(\mathrm{A} 8,17 \mathrm{y})$

\section{DISCUSSION}

To meet their health demands for self-care, adolescents with 1DM emphasize the need to be supported. Support must be offered by health teams through longitudinal and continuous monitoring; by the family, the main source of support, training and monitoring of the transition of care; by the extra-family 
support networks as help from friends and other families who experience the same disease situation; and by the government, providing adequate and timely inputs for 1DM management, responding to the uniqueness of each individual. The social support network has become important because it constitutes interpersonal connections that generate personal protection and social development, being composed from the family nucleus to social systems, such as schools and health services. When there is a strengthened social network, adolescents structure and organize their routine ${ }^{(13)}$ to meet their needs.

PHC assistance has not been effective for most adolescents with 1DM. Faced with dissatisfaction with care, they seek outpatient specialty and hospital services to respond to their health needs. Gaps in self-management support are evident, highlighting problems in advising and arranging this population by FHS resulting from the fragility in professional, organizational and systemic dimensions of healthcare management, which has the function of coordinating care, ordering the flow and counterflow of users in the RAS, favoring continuity of care and connections between the different levels of care.

The lack of coordination of care for adolescents with chronic illness due to PHC and the lack of a defined flow in the RAS for care make it difficult to resolve their health demands in the other network components. Faced with this reality, users are lost with the constant changes in this itinerary in search of building their own networks to try to bring resolvability to their health problems ${ }^{(14)}$.

The unguided search in the different levels of care for the construction of a therapeutic itinerary minimizes the possibilities of bonding, making self-management support and healthcare management unfeasible. This situation was faced by many participants in this study, including not having access to treatment and following for a certain period of time, worsening adolescents' clinical conditions.

A relationship of trust and affection with $\mathrm{PHC}$ professionals generates continuity and longitudinally of care, favoring access, welcoming, bonding, and co-responsibility ${ }^{(15)}$. Conversely, when $\mathrm{PHC}$ health teams are not responsible for assess and assist stages, they are unable to identify adolescents' and families' knowledge about the disease and management, as well as the barriers they face on a daily basis. Consequently, gaps are evident in the individual, family and professional dimensions of healthcare management that have generated unhealthy effects in the lives of these people.

For the family, this situation generates insecurity and mistrust in relation to the assistance provided, especially in $\mathrm{PHC}$, resulting in distance and impairing self-management support, mainly in agree, assist, and arrange phases, indicating the points of vulnerability in the professional dimension of healthcare management in FHS. Furthermore, the absence of a clinical guideline that guides the itinerary for monitoring adolescents with 1DM, according to the complexity of each case, makes it impossible for health professionals to recognize their competence in face of it, hindering coordination of care.

The identified scarcity of educational actions and activities of FHS that help these adolescents in the management and coping with the disease, highlights the need to enhance health education, addressing issues related to diet, insulin application and how the adolescents themselves and their families can recognize the complications. These points constitute a guide for the self-management support assist phase and will strengthen the professional dimension of healthcare management by contributing with the team to develop interventions consistent with the singularities presented by the participants.

Health education is one of the components of the counseling phase, defined as actions that modify behavior and improve knowledge about a specific disease in the unique context ${ }^{(6)}$. Through this educational action, multidisciplinary teams use a preventive and adaptive approach so that adolescents can better adhere to self-care practices in their daily lives ${ }^{(16)}$, by facilitating the appropriation of knowledge and skills for 1DM management ${ }^{(17)}$.

Thus, the team professionals are co-responsible for the guidelines for proper 1DM management, especially in transitions between phases of life in which there are doubts, fears, and challenges. Adolescence must be closely monitored for effective support to meet educational needs and insulin delivery skills and blood glucose testing ${ }^{(18)}$, because, in addition to promoting proper management, it generates confidence for the construction of autonomy for self-care. However, when the actions are focused only on these biological aspects, the clinic is impoverished and the opportunity to promote this autonomy is lost.

Multidisciplinary teams can favor the resolution of complex problems and strengthen the support network. Adolescents with $1 \mathrm{DM}$ feel more supported when there is team intervention in health education, for the development of skills and assessment of personal needs ${ }^{(19)}$. In this study, it became evident that secondary care nursing professionals have welcomed the biopsychosocial needs of adolescents with 1DM by assessing them, advising them, making goal agreements, providing assistance to identify stressors in relation to treatment and making sure of self-care skills, developing health education actions, both individual and collective.

A Canadian survey of 16 and 17-year-old adolescents with 1DM found that health education by nurses, nutritionists and social workers in health services is more efficient when in a group; this education has the potential to provide more in-depth discussions about the disease, peer support, interventions tailored to the demands and interests of those involved, improving adherence to self-care and reducing diabetes-related stress ${ }^{(2)}$.

In contrast, physicians have focused on adjusting insulin treatment without co-participation by adolescents/families, interfering with the early stages of self-management support such as assess, advise, and agree, founded on user-professional trust, and on professional dimension of healthcare management. In the process of medical and nursing education, there are different conceptions about care, and the dispute and asymmetry of powers is evidenced in the focus given to assistance to this population. However, conducting team actions is the principle of building the self-management support cycle to enrich the organizational dimension of healthcare management.

With regard to the transition of responsibility for the care of parents to children with diabetes in adolescence, this must coincide with the maturity of self-efficacy, since the reduction in parental intervention may lead to non-adherence to treatment ${ }^{(20)}$. The findings of this study confirm that it is a delicate 
phase due to the transformation of the life transition itself, which may result in dissatisfaction and inadequate management of the disease. This can intensify parents' concerns and demands regarding their children's attitudes, creating stress in the family relationship. Thus, it is essential to think about the subjectivity of adolescents, their individual sphere, their desires and desires, their modes of social insertion, as this uniqueness implies different ways of taking care of themselves, being able to achieve expanded degrees of autonomy ${ }^{(8)}$.

A study carried out in Chile with adolescents with 1DM from 10 to 17 years old and their mothers pointed out that there is an association between the presence of depression in the mother and the metabolic lack of control of her children with 1DM. Thus, a multidisciplinary family approach is important to obtain better metabolic management in adolescents with 1DM, with adequate psychosocial support for all family members in the transition phase of adolescence ${ }^{(21)}$.

It is understood that these aspects of transition of care must be addressed in healthcare management by professionals in the self-management support assessment phase so that, in the advice phase, knowledge and correct use of techniques are improved. This strengthens the family dimension, reducing the stress of this transition and the impact of the disease.

The extended family has contributed both to the affective, financial and emotional support and to 1DM management when adolescents live with relatives who have diabetes and see the benefits of adherence to treatment on quality of life. Family support combined with a strengthened social support network contributes to overcoming crises and moments of stress, as in the case of lack of inputs for self-care. The exchange of materials and inputs between those who receive larger quantities and those who are disadvantaged is an example of the importance of these networks for continuity of treatment ${ }^{(22)}$.

Another environment that can be a decisive element in these supportive relationships is the school environment, since, at this age, adolescents remain in this environment for a considerable time of the day ${ }^{(17)}$. Therefore, effective communication between family and educators is necessary, as the school has the potential to reverse bullying situations, as well as to add knowledge to understand the disease, bringing adolescents with 1DM closer to their peers in the school environment ${ }^{(20)}$.

Regarding input supply, this is the duty of the State and is found in the corporate dimension of healthcare management, which has the regular function of creating public health policies $^{(8)}$. However, this has placed barriers for this acquisition, such as excessive control and discontinuity of supply, distribution of inputs in different locations and exaggerated bureaucracy for availability, in addition to the mismatch between dispensation and adolescents' needs.

Discontinuity of input supply triggers situations of concern and anguish for waiting, as well as the need for rearrangements in daily life, both interfering in continuity of treatment of a disease that has serious consequences when not properly managed. This fact points to the need for managers to pay attention to the weaknesses of the systemic dimension, in order to prevent clinical complications in these adolescents. Corroborating this assertion, the Brazilian Diabetes Society states that it is essential to distribute free of charge and in sufficient quantity of inputs by the government so that they are not reused, avoiding infections and lipodystrophy ${ }^{(17)}$.

This reality reflects gaps in the corporate dimension that interfere with the implementation of coherent public policies and the government's financial budget programming as well as weakening the systemic dimension. This culminates in losses in individual, family and professional dimensions and makes adolescents with 1DM feel disadvantaged and concerned about the violation of their health rights by those who have a duty to provide. A study emphasizes that this situation interferes with the dignity of the human person, since the health needs of these individuals are not met ${ }^{(23)}$. Therefore, it is extremely important that managers and health staff, through self-management support, observe these barriers related to the lack of materials/inputs. Moreover, it is important to promote the connection between the various points of the support network, using different social media to help them overcome these difficulties and minimize the weaknesses of the systemic and corporate dimensions of healthcare management.

\section{Study limitations}

The study has limitations, such as the selection of adolescents in only one outpatient referral service in a capital of northeastern Brazil, as well as the small number of participants included in the research, which implies caution in generalizations.

\section{Contributions to nursing, health, and public policies}

The study proves to be relevant not only for nursing, but for the entire multidisciplinary health team, as it adds a new look to the ways of producing care; there is little research that addresses self-management support and healthcare management together. The results of this study can also contribute to planning strategic actions in monitoring this population as well as subsidizing and improving public practices and policies in SUS.

\section{FINAL CONSIDERATIONS}

From the perspective of healthcare management, there are many self-management support needs of adolescents with 1DM, going through the disease diagnosis definition, therapeutic itinerary, type of assistance at different levels of health care, support from family, friends and government, as well as fundamental inputs for continuity of care. In this context of the need for selfcare support, there are gaps in the support for adolescents and their families, both from the multidisciplinary health team and from social network members, including the government itself.

This fragility arising from self-care with fragmented support interferes with the individual and family dimensions of healthcare management, which, in turn, may come from professional and organizational dimensions that are not co-responsible for serving adolescents in their singularities, in the perspective of comprehensive, expanded and ethical way. Added to this problem, gaps in systemic and societal dimensions, involving the government and its public policies, which do not guarantee resolving adolescents' and families' needs. 


\section{FUNDING}

This article is part of the scientific initiation project entitled "Necessidade de self-management support de adolescentes com diabetes tipo 1 sob o uso de múltiplas dosagens diárias de insulin e infusão subcutânea contínua de insulin", funded by CNPq Process 305926/2016-0 Productivity in Research, Universidade Federal da Paraíba, 2017-2018.

\section{REFERENCES}

1. Feitor S, Veiga AR, Silva A, Silva V, Duarte S, Rui Sousa M, et al. Empowerment comunitário em saúde escolar: adolescente com diabetes mellitus tipo 1. Rev ROL Enferm [Internet]. 2020 [cited 2020 Nov 11];43(1):364-373. Available from: https://comum.rcaap.pt/ bitstream/10400.26/31492/1/364-373.pdf

2. Mok E, Henderson M, Dasgupta K, Rahme E, Hajizadeh M, Bell L, et al. Group education for adolescents with type 1 diabetes during transition from paediatric to adult care: study protocol for a multisite, randomised controlled, superiority trial (GET-IT-T1D). BMJ Open. 2019;9:e033806. https://doi.org/10.1136/bmjopen-2019-033806

3. Troncone A, Cascella C, Chianese A, Zanfardino A, Piscopo A, Borriello A, et al. Body image problems and disordered eating behaviors in italian adolescents with and without type 1 diabetes: an examination with a gender-specific body image measure. Front Psychol. 2020;11:556520. https://doi.org/10.3389/fpsyg.2020.556520

4. Oluma A, Abadiga M, Mosisa G, Fekadu G, Turi E. Perceived self-efficacy and associated factors among adult patients with type 2 diabetes mellitus at public hospitals of Western Ethiopia. Patient Prefer Adherence. 2020;14:1689-98. https://doi.org/ 10.2147/PPA.S275887

5. Batista AFMB, Nóbrega VM, Gomes GLL, Santos MM, Fernandes LTB, Collet N. [Type 1 Diabetes management: self-management support needs in the transition to adolescence]. Saúde Pesqui. 2020;13(2):363-75. https://doi.org/10.17765/2176-9206.2020v13n2p363-375 Portuguese.

6. Mendes EV. O cuidado das condições crônicas na atenção primária à saúde: o imperativo da consolidação da Estratégia da Saúde da Família [Internet]. Brasília (BR): Organização Pan-Americana da Saúde; 2012 [cited 2020 Oct 08]. 512p. Available from: https://bvsms.saude.gov.br/ bvs/publicacoes/cuidado_condicoes_atencao_primaria_saude.pdf

7. Mororó DD, Enders BC, Lira AL, Silva CMB, Menezes RM. [Concept analysis of nursing care management in the hospital context]. Acta Paul Enferm. 2017;30(3):323-32. https://doi.org/10.1590/1982-0194201700043 Portuguese.

8. Cecilio LCO. Apontamentos teórico-conceituais sobre processos avaliativos considerando as múltiplas dimensões da gestão do cuidado em saúde. Interface. 2011;15(37):589-99. https://doi.org/10.1590/S1414-32832011000200021

9. World Health Organization (WHO). Young people's health - a challenge for society. Report of a WHO Study Group on young people and Health for All by the Year 2000 [Internet]. Geneva (SWI): World Health Organization; 1986 [cited 2020 Aug 15]. 120p. Available from: https:// apps.who.int/iris/bitstream/handle/10665/41720/WHO_TRS_731.pdf?seq

10. Costa BRL. Bola de neve virtual: o uso das redes sociais virtuais no processo de coleta de dados de uma pesquisa científica. Rev Interdiscip Gestão Soc. 2018;7(1):15-37. https://doi.org/10.9771/23172428rigs.v7i1.24649

11. Minayo MCS. Amostragem e saturação em pesquisa qualitativa: consensos e controvérsias. Rev Pesqui Qual [Internet] 2017 [cited 2019 Aug 10];5(7):1-12. Available from: https://www.scielo.br/pdf/csp/v24n1/02.pdf

12. Braun V, Clarke V. Successful qualitative research: a practical guide for beginners. Thousand Oaks: Sage Pub; 2013. 396p.

13. Costa AR, Nobre CMG, Gomes GC, Ribeiro JP, Mota MS, Minasi ASA. Estratégias e rede de apoio social utilizada pela família no cuidado à criança/adolescente com hiv/aids. RSD. 2020;9(7):e28973706. https://doi.org/10.33448/rsd-v9i7.3706

14. Vaz EMC, Collet N, Cursino EG, Forte FDS, Magalhães RKBP, Reichert APS. Care coordination in Health Care for the child/adolescent in chronic condition. Rev Bras Enferm. 2018;71(Suppl 6):2612-9. https://doi.org/10.1590/0034-7167-2017-0787

15. Pedrosa RKB, Guedes ATA, Soares AR, Vaz EMC, Collet N, Reichert APS. Itinerary of children with microcephaly in the health care network. Esc Anna Nery. 2020;24(3):e20190263. https://doi.org/10.1590/2177-9465-ean-2019-0263

16. Chaves FF, Paraiso EC, Pagano AS, Reis IA, Silva IN, Torres HC. Development, validation and adaptation of a protocol for a self-management app targeting adolescents with type 1 diabetes. Acta Paul Enferm. 2020;33:eAPE20190253. https://doi.org/10.37689/acta-ape/2020ao0253

17. Sociedade Brasileira de Diabetes. Diretrizes da Sociedade Brasileira de Diabetes 2019-2020 [Internet]. São Paulo (BR): Clannad Editora Científica; 2019 [cited 2020 Nov 03]. 491p. Available from: https://www.diabetes.org.br/profissionais/images/DIRETRIZESCOMPLETA-2019-2020.pdf

18. American Diabetes Association. Children and Adolescents. Diabetes Care. 2018;38( Supplement 1):S70-ST6. https://doi.org/10.2337/ dc15-S014.

19. Salvy SJ, Ruelas V, Majidi S, Thomas A, Ashwal G, Reid M, et al. Team clinic: expansion of a multidisciplinary care model for adolescents with type 1 diabetes. Contemp Clin Trials. 2020;95:106079. https://doi.org/10.1016/j.cct.2020.106079

20. Collet N, Batista AFMB, Nóbrega VM, Souza MHN, Fernandes LTB. Self-care support for the management of type 1 diabetes during the transition from childhood to adolescence. Rev Esc Enferm USP. 2018;52:e03376. https://doi.org/10.1590/s1980-220x2017038503376 
21. Borries D, Astudillo P, Pérez V, García FH, Rumie K, Garcia BH. Association between depressive symptoms in mothers and metabolic control in adolescents with type 1 diabetes. Rev Chil Pediatr. 2020;91(2):190-8. https://doi.org/10.32641/rchped.v91i2.1151

22. Gomes GC, Jung BC, Nobre CMG, Nörberg PKO, Hirsch CD, Dresch FD. Social support network of the family for the care of children with cerebral palsy. Rev Enferm UERJ. 2019;27:e40274. https://doi.org/10.1590/1982-0194201500029

23. Fernandes DA. A dignidade da pessoa humana: acesso a medicamentos e sua adequação Estatal. Rev Direito (Viçosa). 2020;12(1):1-29. https://doi.org/10.32361/2020120110371 